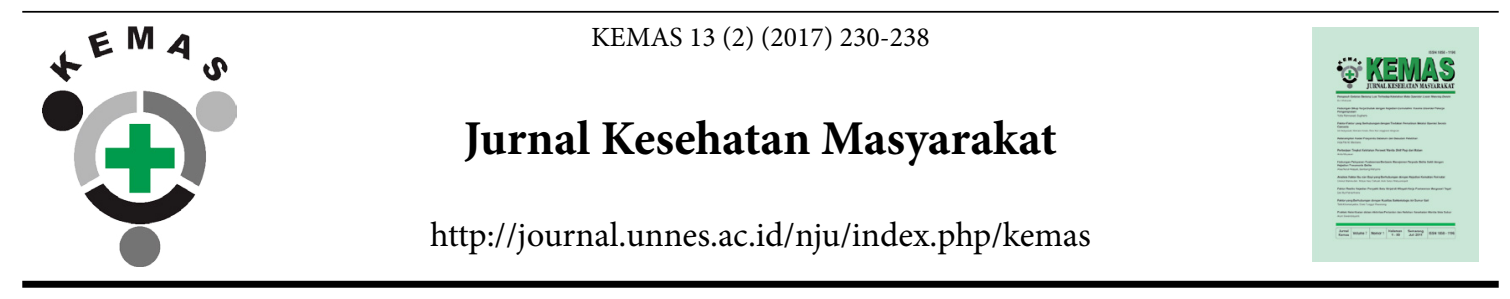

\title{
LEPTOSPIROSIS: NEW EMERGING DISEASE IN SUKOHARJO DISTRICT
}

\author{
Dewi Marbawati ${ }^{1 凶}$, Nova Pramestuti ${ }^{2}$ \\ ${ }^{1,2}$ Balai Litbang P2B2 Banjarnegara
}

\begin{tabular}{l} 
Article Info \\
\hline Article History: \\
Submitted Januari 2016 \\
Accepted November 2017 \\
Published July 2017 \\
\hline Keywords: \\
leptospirosis; rats; Sukoharjo \\
\hline DOI \\
http://dx.doi.org/10.15294/ \\
kemas.v13i2.4849
\end{tabular}

\begin{abstract}
Leptospirosis in Sukoharjo was discovered in 2014. Examination with RDT (Rapid Diagnostic Test) leptotek supported by clinical symptoms showed 6 positive cases of Leptospira, and until March 2015 one person was found to be Leptospira positive. The aim of this study was to identify rats as the main reservoir of leptospirosis, calculate the catching rate of rats and to detect the presence of pathogenic Leptospira in rats. This study was a cross-sectional survey, and was conducted in Pabelan village Kartasura Sukoharjo on May 2015. Polymerase Chain Reaction (PCR) assay was conducted in Bacteriology Laboratory Balai Litbang P2B2 Banjarnegara to detect leptospira in the kidney of the rats. Data were analyzed descriptively. Results of rats and shrew catching obtained Rattus tanezumi, Rattus norvegicus and Suncus murinus. The species most commonly found was balanced between R. tanezumi and S.murinus (46\%). The trap success rate inside and outside the house are $1.50 \%$ and $5 \%$, respectively. Result of laboratory test showed from 13 rats kidneys, two kidneys were found to be Leptospira positive and was from R.tanezumi and R.norvegicus.
\end{abstract}

\section{Introduction}

Leptospirosis is a zoonosis that is widespread globally. World Health Organization (WHO) estimated the incidence of leptospirosis was more than 500,000 cases annually worldwide, with higher incidence in the poor population of developing and tropical countries (Hartskeerl, 2011). Leptospirosis was mostly found in rural area due to the higher risk of human-livestock exposure (Kuriakose, 2008) and also in urban slums with adequate sanitation for rat life as the leptospirosis reservoir (Lacerda, 2008).

The most important leptospirosis reservoir was rodent group, especially rats. Rats, mice, dogs, pigs, and cows were the major source of the infection in humans (Reis, 2008). Leptospira mainly multiply in the kidneys (convoluted tubules). Leptospira would survive and were excreted with urine. Leptospira could survive in the urine for about 8 days to years after infection (Tanzil, 2012). The infected animals showed no symptoms of illness, but only as carriers (maintenance host). Or, they could develop clinical symptoms (accidental host) depending on the infecting serovars (Allan, 2015).

Humans usually acquired infection by contact to urine from the infected host, contaminated water or soil, or infected animal tissue. Leptospira pathogen entered human body through mucosal membrane, conjunctiva, wounded or scratched skin (De Vries, 2014). Transmission could also occur through bite from an animal previously 
infected with leptospirosis or in contact with leptospirosis cultures in the laboratory. Population who had high risk of transmission incidence was those who worked in rice field, animal farm, mining farm, animal slaughter, fishery industry, and veterinary. The activities that were at risk of transmission included river swimming, hunting, and in-forest activity (Tanzil, 2012). The exposure also occurred in daily activities with the higher risk during rainy season and floods. The occupants of urban slums with poor sanitation are also at risk for this disease (Victoriano, 2009).

Sukoharjo District was a new emerging area for leptospirosis. The first leptospirosis case was found in 2014. RDT (Rapid Diagnostic Test)-leptotek supported by clinical manifestations found 6 Leptospira positive cases, whereas until March, 2015, a patient tested Leptospira positive by leptotek. This patient was a woodman with high mobility before being ill, making the disease source difficult to identify (Dinas Kesehatan Kabupaten Sukoharjo, 2015). In December 2014, investigators found two Leptospirosis cases in a sub-village Pabelan Village in RT 01/VIII and RT 03/VIII, Kartasura Sub-District, Sukoharjo District. So they held investigation of rat as reservoir to identify the probability of the Leptospira positive rat in that environment.

This study aimed to identify the caught rats and mice, to study the success rate of rats-catching, and to detect the existence of Leptospira pathogen in rats. Leptospira was examined with Polymerase Chain Reaction (PCR). In recent years, researchers developed PCR protocol using certain target gene in example for detection of Leptospira pathogen. LipL32 was the primary protein component of Leptospira outer membrane that was produced not only in the cultivation period but also during acute and chronic phase. LipL32 is highly immunogenic, evidenced by more than 95\% of Leptospirosis patient showing antibody toward this antigen (Lucas, 2011). Sequences and expression of LipL32 was highly conserved in pathogenic Leptospira, so it is useful as a gene target in pathogenic Leptospira.

Method

This study took place in Pabelan RT 01/ VIII and RT 03/VIII, KArtasura Sub-district,
Sukoharjo District, during May 2015. This was a cross-sectional descriptive study. The research activity includes rats catching, rat identification, kidney sampling, and sample examination to find Leptospira sp. bacteria. The population was rats and mice caught in research location.

The researchers conducted rats and mice catching in settlements using 200 traps at RT 03/ VIII installed both indoor and outdoor for two consecutive nights. The proper consideration for trap installation site was essential to obtain the finest result, for example, considering the footprints or dirt. In order to attract the rats, baits such as coconut or roasted fish were installed into the trap. The trap that had caught another type of rodent would be replaced by a new trap or reused after washed and dried under the sun. Next, the trap with the right rodent would get a label before being put into a fairly strong cloth bag. Then, we brought the bag to process the rat.

The caught rats and mice was given atropine with a dose of $0.02-0.05 \mathrm{mg} / \mathrm{kg}$ body weight of mice for anesthesia, followed by administration of ketamine HCL doses of 50$100 \mathrm{mg} / \mathrm{kg}$ body weight by injecting the thick thighs muscles of the mice. Furthermore, the rats were identified based on Aplin et al (2003) and the catch rate calculated. The rats were then dissected and its kidney removed to confirm the presence of Leptospira bacteria using Polymerase Chain Reaction technique (Balassiano, 2012).

We obtain kidney sample by sterile procedure surgery. Next we obtain a small cut of the kidney tissue and insert it in $1.5 \mathrm{ml}$ microcentrifuge tube, we then added $200 \mu \mathrm{l} \mathrm{GT}$ buffer and $20 \mu \mathrm{l}$ proteinase $\mathrm{K}$ to undergo mixing and incubation for 30 minutes at $60^{\circ} \mathrm{C}$. Then, additional $200 \mu \mathrm{l}$ of GT buffer was immediately inserted into the tube, and we shake it for 10 seconds. We then add $200 \mu \mathrm{l}$ of ethanol immediately and shake it for 10 seconds. We insert GD column in $2 \mathrm{ml}$ collection tube then the sample into the GD column. Next, we centrifuge it for 2 minutes at 14-16,000xg.

After the centrifugation, we removed the collection tube. We replaced it with a new collection tube, and installed the GD column into the tube, then added $400 \mu \mathrm{l}$ W 1 buffer into GD column and then centrifuge it at 14- 
Table 1. Primer for PCR Examination with Target Gene LipL32 (Levett et al., 2005)

\begin{tabular}{llll}
\hline & Primer & Primer Sequences & Band Size \\
\hline pathogenic & LipL32-270F & 5'-CGCTGAAATGGGAGTTCGTATGAT T-3' & \\
Leptospira & LipL32-692R & 5'-CCAACAGATGCAACGAAAGATCCT TT-3' & 423 bp \\
\hline
\end{tabular}

Source : Primary Data

Table 2. Components of PCR Examination with Target Gene LipL32

\begin{tabular}{ll}
\hline Components & Volume $(\mu \mathrm{l})$ \\
\hline Go Taq Green Master Mix, 2x & 12,5 \\
Primer $(10 \mu \mathrm{M})$ : & \\
LipL32- 270F (forward) & 1 \\
LipL32- 692R (reverse) & 1 \\
Nuclease-Free Water & 7,5 \\
DNA Sample & 3 \\
\hline
\end{tabular}

Source : Primary Data

$16,000 x g$ for 30 seconds. Next, we discard the pass-through and placed back the GD column into the collection tube. We added $600 \mu \mathrm{l}$ of wash buffer and centrifuge it at 14-16,000xg for 30 seconds. We discard the pass-through again and return GD column into the collection tube. Then we centrifuged it for 3 minutes at 14 16,000xg until column matrix dried up.

Afterward, we moved GD column into a new $1.5 \mathrm{ml}$ microcentrifuge tube. We added $100 \mu \mathrm{l}$ of warmed up elution buffer into then column matrix and incubate it for 5 minutes in upright position to assure the elution buffer had been well absorbed. Then, we centrifuged it for 30 seconds at $14-16,000 \mathrm{xg}$.

The next phase was PCR examination using Go Taq Green Master Mix (Promega, Cat. \# M7122) kit with specific primer of pathogenic Leptospira as shown in table 1.

We initiated PCR examination by first preparing PCR mix. PCR mix was made in 0.2 $\mathrm{ml}$ PCR tube and was performed in ice, with each reaction $(25 \mu \mathrm{l})$ consisted of components as presented table 2 .

We fused PCR mix in a thermal cycler that was programmed with a denaturation temperature of $95^{\circ} \mathrm{C}$ for 5 minutes, amplified 35 cycles at $95^{\circ} \mathrm{C}$ for 1 minute, $55^{\circ} \mathrm{C}$ for 1 minute (annealing), and $72^{\circ} \mathrm{C}$ for 2 minutes (extension), then for final extension at $72^{\circ} \mathrm{C}$ for 5 minutes.

We then visualized the PCR product using agarose gel electrophoresis with etidium bromide and observed it using 100 bp DNA ladder as a marker to ascertain PCR product.
Interpretation of PCR examination was that 423 bp PCR product was the result of amplification of pathogenic Leptospira target gene LipL32 gene.

Data on the types of caught rats and mice, and the species of mice infected with Leptospira sp bacteria were analyzed descriptively. The rats catch rate was calculated using the formula: (number of captured rats/total number of traps installed) x 100\% (Ristiyanto, 2007).

\section{Result and Discussion}

Sukoharjo District was one of Districs in Central Java Province. Sukoharjo District consisted of 12 Sub-districts and 167 villages. The neighboring areas in the north were Surakarta City and Karanganyar District, in the east was Karanganyar District, in west were Boyolali and Klaten, and in the south were Gunung Kidul District and Wonogiri District (Profile of Sukoharjo District, 2016).

Kartasura was one of sub-districts in Sukoharjo that directly bordered Boyolali District, where Leptospirosis cases were found. This village bordered with Jembungan Village, Banyudono Sub-district of Boyolali District. Boyolali District Health Office had a report of Leptosiprosis case in Jembungan Village.

We reported Leptospirosis cases at RT 01/VIII and RT 03/VIII in Pabelan Village. Both areas were adjoined. We assumed that the Leptospirosis cases emerged due to abundant water pools in early rainy season in 2015. Several mechanisms could explain the association between rainfall and leptospirosis 
incidence. During rainy season, the soil preserved humidity and caused some water pools that supported Leptospira sp. bacteria to survive for long period of time, and increase the human exposure to the bacteria. Meanwhile, during the dry season, the concentration of Leptospira bacteria in the soil was limited to only a few meters. During floods, bacteria could be contagious and reached distant areas due to the flow of water that increased the likelihood of contact with all residents (Desvars, 2011). The high rainfall also caused floods that made many rats came out of hiding and enter residential neighborhoods (Tassinari, 2008). The presence of rainfall differences also increased the human risk of exposure to water surfaces that had been contaminated with Leptospira bacteria (Dassanayake, 2009). Rainwater that was likely contaminated with Leptospira bacteria through rat urine flowed and potentially infected people who did activities around it (Rejeki, 2013).

$$
\text { Epidemiological investigations }
$$

through interviews resulted that both cases of leptospirosis found had similar clinical symptoms with leptospirosis, such as fever, headache, muscles pain (myalgia) and weakness (malaise). One of the interviewed persons had clinical symptoms of muscles pain and calf pain on pressure. In the early stages, common manifestation of leptospirosis in humans was a non-specific febrile illness that was difficult to distinguish from the etiology of other febrile diseases in the tropics. Infection could develop into severe secondary symptoms including renal failure and pulmonary hemorrhagic syndrome, and a death rate of up to $50 \%$ had been reported (Allan, 2015).

Epidemiological investigations also suggested that both cases of leptospirosis had a history of contact with puddles. Puddle alone was known to be one of the risk factors for leptospirosis (Anies, 2009; Riyaningsih, 2012; Svircev, 2009). Both leptospirosis patients were also known to have a history of wounds on foot, one of them even stated a history of disposing a dead mouse while cleaning his warehouse and had cleaned the water channel in front of his house.

The results of the rat catching in Pabelan Village, Kartasura Sub-district, showed taht the trap catch rate inside and outside the house was
$1.50 \%$ and $5 \%$, respectively. When we compared with a study in Bangetayu Kulon Village, Genuk Sub-district of Semarang City, Jeron Village and Sindon Village of Boyolali District, the catch rate in Pabelan Village was relatively low. The catch rate in Bangetayu Kulon reached 13.78\% (Irawati, 2015), in Jeron village reached 16.49\% and in Sindon village was $10.75 \%$ (Widiastuti, 2016). According to Hadi (2007), catch rate in normal condition was $7 \%$ inside the house and $2 \%$ outside. The success of this catch could roughly illustrate the rat population density in the area.

Factors influencing catch rate include: feeding bait installation, type of traps, site of the traps, and behavior of rats. Bait installation should be tailored to the availability of feed sources the rats usually feed on in the local area. Traps used to catch the rats had to be strong. Trap conditions prior to installation should be check for any damage so rats could not escape (only stealing the bait installed). The site of traps installation also affected the success of rats catching. Traps were placed in places usually crossed or visited by rats, such as kitchens or roofs. The behavior of rats that influenced the catch rate was its good sense of tactile and hearing that quickly help it learn the unfavorable conditions for its life. Also, if a rat had experienced eating a certain kind of food that caused severe stomach pain, then the rat would not eat it for a second time. However, the rat would try to eat it again after some time (Astuti, 2013).

Other factors affecting the success of rat catch are its activity. Rats are most active at night, and during daytime they shelter themselves in the hole or bushes. Trap was set up at night to maximize the catch rate (Irawati, 2015). Holes were needed when catching during the daytime. Rat have neophobia trait, which mean they are cautious to any new object in their environment. Neophobia often resulted in a very low catch at the first night. The following nights have higher catches as the neophobia of the rat had dissipated. Setting up the trap at the right place will affect success of the capture. Trap should be placed where rats are likely to be abundant (Aplin, 2003).

Rat and mice species found were Rattus tanezumi, Rattus novergicus and Suncus 


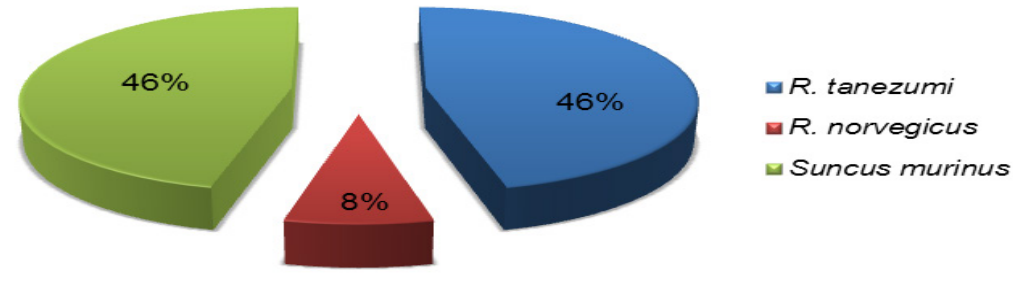

Figure 1. Rat and mice species found at Pabelan Village, Kartasura sub-district, Sukoharjo district, year 2015 .

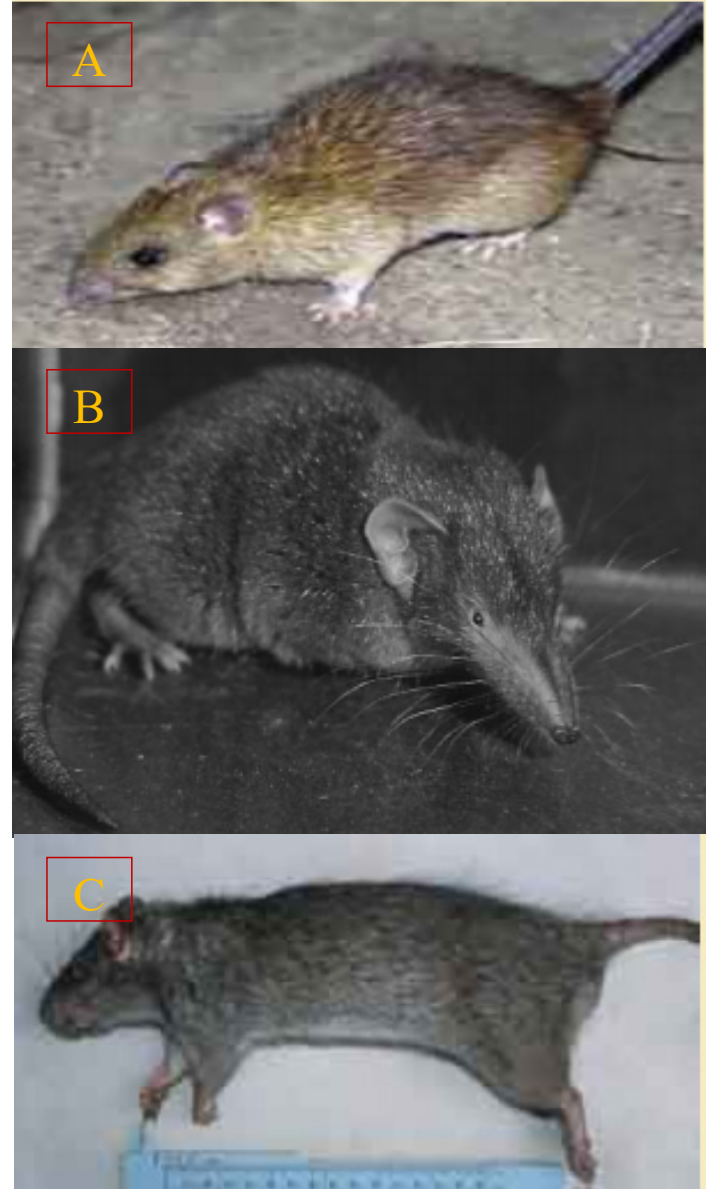

Figure 2. Morphology of Rattus tanezumi (A), Suncus murinus (B), and Rattis norvegicus (C). Source: Aplin, 2003 (A and C) and Temple, 2004 (B).

murinus, most of which were $R$. tanezumi and S. murinus both comprising $46 \%$ of all.

Morphologically, the caught $R$. tanezumi have the following characteristics: rough hair pattern, cone-shaped nose, cylindrical body, black-brown-greyish back and stomach, and brown-black upper tail. According to Aplin (2003), $R$. Tanezumi have a total length of (TL) $172-230 \mathrm{~mm}$, tail length (T) $176-237 \mathrm{~mm}$, hindfoot length (HF) $35-43 \mathrm{~mm}$, earlobe width (E) $22-28 \mathrm{~mm}$, body weight (W) up to 219 grams and mamae formula of $2+3$ that means 2 pairs of mamae at the chest and 3 pairs at the stomach. House rat (R. tanezumi) is a domestic rat which lives its life near human. Its entire life activity such as hunting for food, sheltering, nesting, and reproducing took place at human houses.

Suncus murinus/mice has the following characteristic: pointy snout, short tail, slow moving, wet feces, and bad odor produced from its glands near the butt when passing by. Mice's short tail become its defined feature and tells that this animal is not skilled enough to climb. Wet feces indicate that its main prey is insect (animal protein). Quantitative morphological characteristics are as follow, total length (TL) 180-205 mm, tail length (T) $64-78 \mathrm{~mm}$, hindfoot length (HF) 17-21 mm, earlobe width (E) 4-14 $\mathrm{mm}$, body weight (W) 30-60 gram and mamae formula by $0+3$, means that it have 3 pairs of mamae at stomach (Ristiyanto, 2007). Actually, Suncus murinus does not belong to rat families, but it belongs to insectivore families. Mice play a role in leptospirosis infection. Suncus murinus can adapt with house environment. This species not only eat insect as their food but human leftovers as well (Ikawati, 2012). Study showed that in Gresik districts, S. murinus positively contain Leptospira bacteria such as Leptospira hardjo, L. bataviae, and L. icterohaemorrhagie (Yunianto, 2012). Other study by Ikawati (2012), also found Leptospira bacteria in S. murinus. 
Rattus norvegicus have a characteristic of digging a hole and residing in there. It weigh between 230-510 gram, with a total length of (TL) 205-260 mm, tail length of (T) 190-260 $\mathrm{mm}$, hindfoot length (HF) $27-44 \mathrm{~mm}$, earlobe width (E) 17-22 mm, body weight of (W) 230 510 gram, and mamae formula of $3+3$, which means that it have 3 pairs of mamae in the chest and 3 pairs in the abdomen. This species has grey-brown color on its back and is pale-brown or grey at the stomach. The tail is almost always shorter than the head and body. The upper-tail has darker color whereas the lower has lighter color. It also has rigid short hair. Its ears are relatively small and half of it is covered in fur (Aplin, 2003).

Rattus norvegicus are usually called sewer rat as it lives in urban underground sewer whether it is small or big near human residences. Sewer rats ( $R$. norvegicus) usually lives at the lower part of a building and the nearby area (dump, hole nests, big river bank or irrigation). Rats that reside in water area tend to be infected by Leptospira, such as sewer rats ( $R$. norvegicus) (Yunianto, 2012).

Rat catch results by its location (inside or outside house) in Pabelan Village, Kartasura sub-district, Sukoharjo district is presented in the following graph.

Figure 3 shows that $R$. tanezumi was equally found inside or outside of the house. $R$. novergicus was frequently found outside while mice ( $S$. murinus) was found inside. Food availability is higher inside, but nesting place and explorable area is much greater

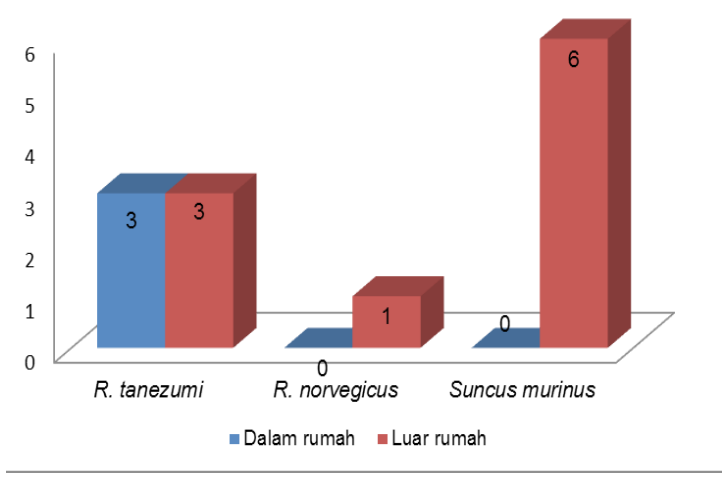

Figure 3. Rat catch results by its capture location in Pabelan Village, Kartasura sub-district in 2015. outside due to cattle pen, large garden, various trees, and ornamental plants. Inside the house (where there are lots of rat trap, especially in the kitchen) rats have access to a lot of food ingredients (Ikawati, 2011).

Our rat capture data of $R$. tanezumi and $R$. norvegicus showed that most of the rat found were female. This result is in line with Ikawati (2011), in Klaten district and Yunianto (2012), in Gresik district that showed the majority of the rat captured were female. Likewise, Ikawati and Sunaryo (2012), found more female rats (60 rats) than male rats (49 rats). Priyambodo in Yunianto (2012), thought that female rats were easier to catch than male and it was related to its role in their community as they are the one to provide food for their children resultingin female rat having higher mobility in their group. Rats behavior like protecting the nest and fightintruders in male rats, and nurturing instinct and caring for children in female rats, are influenced by pituitary and sexes hormone from endocrine glands in hypothalamus, that is in the base and side of the thick part in third ventricle from the front part of the rat brain (diencephalon).

As for preferences for food bait, most prefer grilled coconut (69\%) than grilled salted fish. This in line with Wijayanti (2008), that states $R$. tanezumi and $R$. norvegicus prefer grilled coconut than others. Coconut as the rat's favorite of is one of the reason it was used as bait to catch the rats in some study. Coconut is full of easy-to-digest fat, nutritious, have hard texture and rich in calorie. Proteins inside coconut contain all various amino acid structures. Moreover, it is rich in potassium, magnesium, and sulfur. Other than its high level of calorie, the unique scent of grilled coconut attracts rat's sense of smell. Coconut is relatively hard than grilled salted fish, and that sharpen the rat's teeth (Wijayanti, 2008).

In this study, Leptospira detection inside kidney used target LipL32 gene. LipL32 gene is a specific gene in pathogenic Leptospira. Leptosipra detection in 13 rat kidneys from Pabelan Village found 2 positive kidneys containing Leptospira from $R$. tanezumi and $R$. norvegicus species. Leptospira detection method using PCR (Polymerase Chain Reaction) were based on amplification of a specific 
DNA segment of Leptospira. The benefit of PCR method is that bacterial existence can be quickly detected especially in the early phase of Leptospira disease before antibody titer can be detected. PCR method can also be performed in various places in Leptospira genome resulting in higher reliability (Widiastuti, 2016). Joshi and Despande (2010), explained that PCR method has high accuracy as DNA amplification is performed specifically, so very few DNA in a sample can still be detected. The weakness of this method is, it requires advanced equipment and skilled operator, false positive results can occur as a result of foreign DNA contamination, and false negative can appear due to clinical specimen containing inhibitors such as heparin and saponin. PCR results in rat kidney with LipL 32 gene target can be seen in the figure 4 .

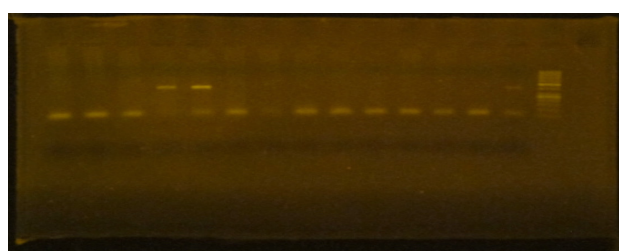

Figure 4. Picture of PCR Electrophoresis product from rat kidney. M: Marker $100 \mathrm{bp}$ ladder, K: Leptospira positive control, Lane 1-13 Sample No $1-13$

PCR with LipL 32 gene target obtained positive result in $423 \mathrm{bp}$ that is an amplification from a Leptospira pathogen. Positive sample in sample number 4 and 5 originated from $R$. tanezumi and $R$. novergicus kidney. Both species are found to be a reservoir of Leptospira pathogen in Semarang (Yunianto, 2010). Species domination of leptospirosis reservoir was seen from epidemiological aspect of transmission to the infected environment. Most likely, infected human were exposed to Leptospira by $R$. tanezumi because of its habitat that are nearby. Applin (2003), explained that this rat is commonly found in urban and rural area. Leptospira infection in R. tanezumi is suspected to be naturally conserved with vertical (offspring) and horizontal (interreservoir) transmission. The natural host reservoir can carry Leptospira strain in their kidney and contaminate their urine in a long period of time, sometime its whole life.
Leptospira infection in rats is influenced by its species (Ikawati, 2012). Difference in infection prevalence of rat differing species was caused by factors influencing infection between certain rodent population, as well as study site and method.

Study by Sumanta (2015), mentioned of 99 rat kidneys examined for Leptospira DNA, 25 came out positive using qPCR and 6 was positively confirmed for pathogenic Leptospira using standard PCR. Pathogenic Leptospira examination using LipL 32 gene target were already performed in water sample from nine villages in Demak district and resulted $46.7 \%$ positively containing pathogenic Leptospira DNA (Widiastuti, 2015). Leptospira depended on environment $\mathrm{pH}$, temperature and presence of pollutant. Leptospira is sensitive to acidity and can live in water for about 1 month. In sea water, waste product, and pure urine, the bacteria will quickly die. Leptospira can live for around 3 weeks in flooded area. This shows that Leptospira survived in the environment and can be a source of infection that is excreted in rat urine for a long time, and Leptospira can also live in suitable environment for months (Widiastuti, 2016).

Leptospira species that is transmitted through rats is the most dangerous to human compared to all Leptospira in other domestic animals. Rat excrete high concentration of Leptospira $\left(10^{7}\right.$ organism per $\left.\mathrm{ml}\right)$ during the following months after being infected (Evangelista, 2010). Leptospira infection in rats is directly proportional to its age, the amount of Leptospira increasing in its body as it ages (Ristiyanto, 2007). This is a source of infection in human and other animals, therefore prevention and control of Leptospira reservoir should be conducted comprehensively, for example, by catching rat periodically using trap to decrease rat population inside the house and neighborhood.

\section{Conclusion}

Mice and rat species caught in Pabelan Village, Kartasura sub-district, Sukoharjo district are Rattus tanezumi, Rattus norvegicus and Suncus murinus with catch success rate (trap success) inside and outside of the house $1.50 \%$ and $5 \%$, respectively. Laboratory examination using PCR with LipL 32 gene target from rat 
kidneys showed positive results of Leptospira pathogen from rat species of $R$. tanezumi and $R$. novergicus. Although Sukoharjo district are a new area with Leptospira problem and have low success catch rate, positive Leptospira finding in rat means there need to be caution because source of infection had been found. Leptospirosis can be anticipated by leptospirosis screening in human and control of rat by society and also leptospirosis socialization to various parties nearby (society, health workers, and governments). Actions taken are primarily by improving early detection and control or prevention with clean and healthy lifestyle, especially waste dumping, soap hand washing, using protective equipment when working in flood or puddle of water area, good foot wound treatment, improving nutrition to increase immunity against diseases and protection against rats.

\section{References}

Allan KJ, Biggs HM, Halliday JEB, Kazwala RR, Maro VP, Cleaveland S, et al. 2015. Epidemiology of leptospirosis in Africa: a systematic review of a neglected zoonosis and a paradigm for 'One Health' in Africa. PLoS Negl Trop Dis, 9(9)

Anies, Hadisaputro S, Sakundarno AM, Suhartono. 2009. Lingkungan dan perilaku pada kejadian Leptospirosis. Media Medika Indonesia, 43(6):306-311.

Aplin KP, Brown PR, Jacob J, Krebs C, Singleton GR. 2003. Field methods for rodent studies in Asia and the Indo-Pacific. Canberra: ACIAR Monograph No.100.

Astuti DR. 2013. Keefektifan rodentisida racun kronis generasi II terhadap keberhasilan penangkapan tikus. KEMAS, 8(2):183-189.

Balassiano IT, Vital-Brazil JM, Pereira MM. 2012. Leptospirosis diagnosis by immunocapture polymerase chain reaction: a new tool for early diagnosis and epidemiologic surveillance. Diagnostic Microbiology and Infectious Disease, 74:11-15.

Dassanayake DLB, Wimalaratna H, Agampodi SB, Liyanapathirana VC, Piyarathna TACL, Goonapienuwala BL. 2009. Evaluation of surveillance case definition in the diagnosis of leptospirosis, using the Microscopic Agglutination Test: a validation study. BMC Infectious Diseases, 9(48). http://doi. org/10.1186/1471-2334-9-48.

De Vries SG, Visser BJ, Nagel IM, Goris MGA, Hartskeerl RA, Grobusch MP. 2014.
Leptospirosis in Sub-Saharan Africa: a systematic review. International Journal of Infectious Diseases, 28:47-64.

Desvars A, Jego S, Chiroleu F, Bourhy P, Cardinale E, Michault A. 2011. Seasonality of human leptospirosis in Reunion Island (Indian Ocean) and its association with meteorological data. PLoS ONE, 6(5):e20377. doi:10.1371/journal.pone.0020377

Dinas Kesehatan Kabupaten Sukoharjo. 2015. Laporan kasus leptospirosis tahun 20142015. Sukoharjo: Dinkes Sukoharjo

Evangelista KV, Coburn J. 2010. Leptospira as an emerging pathogen: a review of its biology, pathogenesis and host immune responses. Future Microbiol, 5 (9): 1413-1425.

Hadi BS, Basuki N, Setyalastuti, Setiawan YD. 2007. Monitoring faktor risiko lingkungan leptospirosis di Kota Semarang Propinsi Jawa Tengah. Buletin Epidemiologi Lingkungan BBTKL PPM Yogyakarta, 1 (2): 51-67.

Hartskeerl RA, Collares-Pereira M, Ellis WA. 2011. Emergence, control and re-emerging leptospirosis: dynamics of infection in the changing world. Clin Microbiol Infect, 17 (4):494-501.

Ikawati B, Yunianto B, Ramadhani T. 2011. Studi fauna tikus dan cemice di daerah ditemukan kasus leptospirosis di Kabupaten Klaten, Provinsi Jawa Tengah. BALABA, 7 (2): 40-45.

Ikawati B, Sunaryo, Widiastuti D. 2012. Dominant factors influencing Leptospira sp infection in rat and suncus. Health Science Indonesia, 3(2):27-30.

Ikawati B, Sunaryo. 2012. Strain Leptospira yang ditemukan pada tikus dan suncus di Kecamatan Minggir Kabupaten Sleman. Prosiding Seminar Nasional Kesehatan Jurusan Kesehatan Masyarakat FKIK UNSOED Purwokerto, 31 Maret 2012.

Irawati J, Fibriana AI, Wahyono B. 2015. Efektivitas pemasangan berbagai model perangkap tikus terhadap keberhasilan penangkapan tikus di Kelurahan Bangetayu Kulon Kecamatan Genuk Kota Semarang Tahun 2014. Unnes Journal of Public Health, 3: 67-75.

Joshi M and Deshpande JD. 2010. Polymerase Chain Reaction: Methods, Principle and Application. International Journal of Biomedical Research, 1(5):81-97.

Kuriakose M, Paul R, Joseph MR, Sugathan S, Sudha TN. 2008. Leptospirosis in a Midland Rural Area of Kerala State. Indian J Med Res, 128 (3): $307-312$.

Lacerda HG, Monteiro GR, Oliveira CC, Suassuna FB, Queiroz JW, et al. 2008. Leptospirosis in 
a subsistence farming community in Brazil. Trans R Soc Trop Med Hyg, 102 (12): 12331238.

Levett PN, Morey RE, Galloway RL, Turner DE, Steigerwalt AG, Mayer LW. 2005. Detection of pathogenic leptospires by Real-Time Quantitative PCR. Journal of Medical Microbiology, 54: 45-49.

Lucas DS, Cullen PA. Lo. M, Srikram A, Sermswan RW, Adler B. 2011. Recombinant LipL32 and LigA from Leptospira are unable to stimulate protective immunity against leptospirosis in the hamster model. Vaccine, 29 (18): 34133418.

Munoz-Zanzi C, Mason M, Encina C, Gonzalez M, Berg S. 2014. Household characteristics associated with rodent presence and leptospira infection in rural and urban communities from Southern Chile. Am.J.Trop.Med.Hyg., 90(3):497-506.

Profile of Kabupaten Sukoharjo. 2016.

Reis RB, Ribeiro GS, Felzemburgh RD, Santana FS, Mohr, S., et al. 2008. Impact of environment and social gradient on Leptospira infection in urban slums. PLoS Negl Trop Dis, 2(4).

Rejeki DSR, Sri N, Devi O. 2013. Pemetaan dan analisis faktor risiko leptospirosis. Jurnal Kesehatan Masyarakat Nasional, 8(4):179186.

Ristiyanto. 2007. Modul pelatihan teknis tingkat dasar survei reservoir penyakit bidang minat rodensia. Salatiga: Balai Besar Penelitian dan Pengembangan Vektor dan Reservoir Penyakit.

Riyaningsih, Hadisaputra S, Suhartono. 2012. Faktor risiko lingkungan terhadap kejadian leptospirosis di Jawa Tengah (studi kasus di kota Semarang, Kabupaten Demak dan Pari). Jurnal Kesehatan Lingkungan. 11(1):87-94.

Sumanta H, Wibawa T, Hadisusanto S, Nuryati A, Kusnanto H. 2015. Genetic variation of Leptospira isolated from rats catched in Yogyakarta Indonesia. Asian Pacific Journal of Tropical Medicine, 8 (9): 710-713.

Svircev Z, Markovic MJ, Vukadinov J, Mikic SS,
Ruzic M, Doder R et al. 2009. Leptospirosis distribution related to freshwater habitats in the Vojvodina Region (Republic of Serbia). Sciences in China Series: Life Sciens, 52(10).

Tanzil, K. 2012. Ekologi dan Patogenitas Kuman Leptospira. Widya, 29 (324): 10-13.

Tassinari WS, Pellegrini DC, Sa CB, Reis RB, Ko Al, Carvalho MS. 2008. Detection and modeling of case clusters for urban leptospirosis. Trop Med Int Health. 13(4): 503-12.

Temple JL. 2004. The musk shrew (Suncus murinus): a model species for studies of nutritional regulation of reproduction. ILAR Journal, 45(1): 25-34.

Victoriano AFB, Smythe LD, Gloriani-Bazarga N, Cavinta LL, Kasai T, Limpakarnjanarat K, et al. 2009. Leptospirosis in the Asia Pacific Region. BMC Infectious Disease, 9(147).

Widiastuti D, Djati, AP. 2015. Kontaminasi Leptospira Patogenik pada air konsumsi di pemukiman Kabupaten Demak. BALABA, 11 (2): 89-96.

Widiastuti D, Sholichah Z, Agustiningsih, Wijayanti N. 2016. Identification of pathogenic Leptospira in rat and shrew populations using rpoB gene and its spatial distribution in Boyolali District. Kesmas: National Public Health Journal, 11 (1):32-38.

Wijayanti, T., Hariastuti, N.I., Isnani, T., Ismanto, H., Ustiawan, A. 2008. Bait preference of domiciliary rats trapped in leptospirosis endemic area of Demak District. Proceeding International Seminar in Zoonotic and Tropical Disease. Yogyakarta, 26-27 June 2009. 61-67.

Yunianto B, Ramadhani T, Ikawati B, Wijayanti T, Jarohman. 2012. Studi reservoir dan distribusi kasus leptospirosis di Kabupaten Gresik Tahun 2010. Jurnal Ekologi Kesehatan, 11(1):40-51.

Yunianto, B, Ramadhani T. 2010. Kajian epidemiologis kejadian leptospirosis di Kota Semarang dan Kabupaten Demak Tahun 2008. BALABA, 6(1):7-11. 